Vol 1. No. 4, Oktober 2021 P-ISSN : 2774-8030, e-ISSN : 2774-8030

\title{
PEMBELAJARAN JARAK JAUH PADA MASA PANDEMI COVID-19 DI SMP NEGERI 2 TARAKAN
}

\section{MOCHAMMAD MACHFUD}

SMP Negeri 2 Tarakan

Email : mmasfud@gmail.com

\begin{abstract}
ABSTRAK
Penulisan ini bertujuan untuk mengeksplorasi pembelajaran jarak jauh yang dilaksnakan di SMP Negeri 2 Tarakan dapat berjalan dengan baik, agar tujuan pendidikan bisa tercapai. Laporan pelaksanaan Pembelajaran Jarak Jauh merupakan pelaporan hasil pelaksanaan pembelajaran yang dilakukan oleh guru mata pelajaran PPKn kelas 9 di SMP Negeri 2 Tarakan, Kota Tarakan, Kalimantan Utara dalam hal bagaimana penerapan pembelajarannya, menggunakan kurikulum darurat selama pandemi Covid-19, alat dan media apa yang digunakan serta prestasi belajar siswanya Langkah-langkah Langkah seperti meliputi perencanaan pembelajaran, pelaksanaan pembelajaran dan evaluasi, Dari hasil pelaksanaan pembelajaran jarak jauh terdapat beberapa kendala dalam pelaksanaannya akan tetapi bisa diselesaikan dengan baik demi mencerdaskan perserta didik. Baik sistem pembelajaran daring dan luring diharapkan guru dapat kreatif dalam mendidik peserta didik, supaya keberhasilan pembelajaran bisa tercapai dengan baik atau efektif. Penulisan ini memberikan informasi bahwa guru sebenarnya lebih senang memilih pembelajaran luring di mana bisa berinteraksi langsung dengan siswa, dan juga siswa lebih menyukai pembelajaran luring melalui pembelajaran tatap muka. Karena pandemi Covid-19 masih tinggi maka pelaksanaan pembelajaran jarak jauh dengan system daring masih menjadi pilihan alternatif yang terbaik demi keselamatan guru, warga sekolah dan peserta didik itu sendiri.
\end{abstract}

Kata Kunci: Pembelajaran Jarak Jauh, Pembelajaran Daring, Pembelajaran Luring, Masa Pandemi Covid-19

\section{PENDAHULUAN}

Pendidikan merupakan usaha sadar dan terencana untuk memberikan bimbingan dan pertolongan dalam mengembangkan potensi anak baik jasmani ataupun rohani yang dimana di berikan oleh orang dewasa kepada anak untuk mencapai kedewasaannya serta mencapai tujuan anak menjadi manusia yang beriman, berakhlak mulia, berilmu, kreatif dan mandiri yang dapat di terima di dalam masyarakat. Pendidikan akan memberikan pengalaman-pengalaman belajar di dalam program-program pendidikan formal, nonformal atau informal di sekolah. Sesuai yang diamanatkan dalam Undang-undang Sistem Pendidikan Nasional No. 20 Tahun 2003 pasal 3 menyatakan bahwa tujuan pendidikan nasional adalah untuk mengembangkan potensi peserta didik agar menjadi manusia yang beriman dan bertakwa kepada Tuhan Yang Maha Esa, berakhlak mulia sehat, berilmu, cakap, kreatif, mandiri dan menjadi warga negara yang demokratis serta bertanggung jawab (Republik Indonesia, 2003; Murkatik dkk, 2020; Abdullah, 2020; Apriani dkk, 2020; Amalia, 2019).

Sekolah merupakan institusi yang diharapkan dapat membentuk karakter generasi muda. Dalam kontek ini pendidikan dimaknai sebagai proses untuk memanusiakan manusia untuk menjadi manusia dewasa seutuhnya. Melalui pendidikan di semaikan pola pikir, nilai- nilai, dan norma-norma di masyarakat (Rohma dkk, 2020; Zulaiha dkk, 2020; Hartiwi dkk, 2020).

Akan tetapi dunia di kejutkan dengan mewabahnya suatu penyakit yang di sebabkan oleh sebuah virus yang bernama corona atau dikenal dengan Covid-19 (Corona Virus diseases-19). Yang mulai mewabah 31 Desember 2019 di Kota Wuhan Propinsi Hubei Tiongkok, dan penyebaran virus tersebut saat ini ke seluruh dunia dengan sangat cepat, sehingga WHO tanggal 11 Maret 2020 menetapkan sebagai pademi global. Ratusan ribu manusia terpapar virus ini di seluruh dunia, bahkan menyebabkan puluhan ribu orang meningggal dunia. Tercatat beberapa 
negara yang menjadi kasus tertinggi terpapar Covid-19 yaitu Italia, Amerika Serikat, Tiongkok, Spanyol, dan Iran. Bahkan juga Indonesia terkena dampaknya.

Penularan lewat kontak sosial antara manusia sulit di prediksi dan juga tidak bisa di hindari sehingga penyebarannya juga sangat pesat. Obat penawar juga belum bisa ditemukan menjadi penyebab banyaknya kematian. Rumitnya penanganan wabah ini membuat para pemimpin dunia dan termasuk Indonesia membuat kebijakan super ketat untuk memutus mata rantai penyebaran Covid-19 yaitu dengan menerapkan social distanding (pembatasan interaksi sosial).

Social distancing sendiri berarti tindakan dengan memberi jarak atau menghindari keramaian atau menghindari kontak dalam jarak dekat dengan orang lain. Atau dijelaskan oleh Center for Disease Control (CDC), social distancing merupakan tindakan menjauhi perkumpulan orang dalam jumlah besar, menghindari pertemuan massal dan menjaga jarak antar manusia.

Dengan penerepan social distanding (pembatasan interaksi social) berdampak juga dalam dunia pendidikan. Pemerintah membuat keputusan untuk meliburkan atau memindahkan proses pembelajaran yang tadinya di sekolah menjadi di rumah. Peralihan pembelajaran ini mamaksa dunia Pendidikan terutama guru untuk berinovasi mengikuti jalur yang bisa ditempuh agar pembelajaran dapat berlangsung dengan cara memanfaatkan teknologi sebagai media pembelajaran daring. Penggunaan teknologi ini juga sebenarnya terdapat beberapa masalah seperti penguasaan teknologi yang masih rendah, keterbatasan sarana dan prasarana, jaringan internet, biaya, dan motivasi guru serta siswa yang menurun karena bosan menggunakan teknologi tersebut (Komalasari dkk, 2020; Fitria dan Suminah, 2020; Hamzah dkk, 2020; Rohma dkk, 2020).

Istilah pembelajaran daring dan luring di perkenalkan di era teknologi informasi pada saat ini, pembelajaran daring merupakan singkatan dari pembelajaran dalam jaringan, atau pengganti istilah pembelajaran online yang sering kita gunakan dalam teknologi internet (Ivanova dkk, 2020; Kristiawan dan Muhaimin, 2019; Kristiawan, 2014). Menurut Ivanova dkk (2020) pembelajaran daring artinya adalah pembelajaran yang dilakukan secara online, menggunakan aplikasi pembelajaran maupun jejaring sosial. Pembelajaran daring merupakan pembelajaran yang dilakukan tanpa melakukan tatap muka, tetapi melalui platform yang telah tersedia. Segala bentuk materi pelajaran didistribusikan secara online, komunikasi juga dilakukan secara online, dan tes juga dilaksanakan secara online. Sistem pembelajaran melalui daring ini dibantu dengan beberapa aplikasi, seperti Google Classroom, Google Meet, Edmudo dan Zoom. Sedangkan menurut Hamid Muhammad sebagai plt. Dikdasmen Kemendikbud pembelajaran daring adalah pembelajaran yang menggunakan model interaktif berbasis internet dan Learning Manajemen System (LMS). "Pembelajaran daring ini dilakukan selama ini secara interaktif seperti Zoom, Google Meet. Itu salah satu (pembelajaran) yang kami sarankan agar ada interaksi antar guru dan murid di mana (catatannya) tak ada hambatan di gawai, internet, dan pulsa. Sedangkan pembelajaran luring merupakan singkatan dari pembelajaran di luar jaringan atau dengan istilah offline, artinya pembelajaran ini tidak lain merupakan pembelajaran konvesional yang sering digunakan oleh guru sebelum adanya pandemi Covid-19 akan tetapi ada perubahan tertentu seperti jam belajarnya lebih singkat dan materinya sedikit (https://www.kompas.com/edu/read/2020/06/16/200131471/pembelajaranjarak-jauh-bukan-pembelajaran-daring-ini-penjelasannya). Pembelajaran dengan metode Luring atau offline merupakan pembelajaran yang dilakukan di luar tatap muka oleh guru dan peserta didik, namun dilakukan secara offline yang berarti guru memberikan materi berupa tugas hardcopy kepada peserta didik kemudian dilaksanakan di luar sekolah (https://www.kemdikbud.go.id/main/blog/2020/05/kemendikbud-terbitkan-pedomanpenyelenggaraan-belajar-dari-rumah)

Di masa pandemi Covid-19 banyak cara dilakukan pihak sekolah untuk pembelajaran tetap berlangsung seperti menerapkan pembelajaran daring dan pembelajaran luring. Walaupun terkadang tujuan pembelajaran yang ingin di sampaikan belum tercapai dengan baik, akan tetapi 
di harapkan dari proses tersebut di harapkan perserta didik mampu menerima pembelajaran baik pembelajaran daring ataupun pembelajaran luring. Termasuk upaya yang di lakukan sekolah untuk mencerdaskan peserta didiknya (Zulaiha dkk, 2020; Soleh dkk, 2019; Septiani dan Cahyono, 2019; Nugraha, 2019; Listiningrum dkk, 2020).

\section{METODE PENELITIAN}

Dalam penelitian ini menggunakan penelitian kualitatif dengan jenis metode fenomenologi, yang di mana penelitian ini tujuannya untuk melihat fenomena yang terjadi dalam kehidupan di masyarakat, metode fenomenologi menggali data untuk menentukan fenomena esensial seperti pengamalaman dari seorang peneliti. Tujuan penelitian ini adalah untuk mencari tahu bagaimana penerapan pembelajaran daring dan pembelajaran luring mata pelajaran PPKn kelas 9 di SMP Negeri 2 Tarakan di Kota Tarakan, Kalimantan Utara. Menurut (Sugiyono, 2017) yang di maksud dengan metode penelitian adalah metode penelitian pada dasarnya merupakan cara ilmiah untuk mendapatkan data dengan tujuan dan kegunaan tertentu. Jadi metode penelitian adalah merupakan suatu cara mencari, memperoleh, menyimpulkan, atau mencatat data, baik primer ataupun skunder yang dimana digunakan untuk keperluan menyusun karya ilmiah. Dalam penelitian ini penulis berkolaborasi dengan guru guru yang mengajar mata pelajaran PPKn baik guru kelas 7 maupun guru kelas 8 . Langkahlangkah penelitian ini meliputi perencanaan tindakan, pelaksanaan tindakan, tahap pengamatan, dan tahap refleksi.

\section{HASIL DAN PEMBAHASAN}

Penelitian ini diadakan di SMP Negeri 2 Tarakan, Kota Tarakan, Kalimantan Utara, sekolah tersebut telah mengadakan pembelajaran daring dan pembelajaran luring di semester genap tahun pelajaran 2020/2021 ini, sebelumnya sekolah telah mengadakan pembelajaran daring di semester genap di tahun pelajaran 2019/2020.

Langkah-langkah tugas yang diambil sebelum pelaksanaan daring yaitu tugas kepala sekolah 1) mengadakan rapat dinas dengan guru dan karyawan kemudian kepala sekolah memberikan surat tugas kepada guru untuk melakukan kegiatan pembelajaran di rumah sesuai dengan kelas atau mata pelajaran yang diampu guru, melalui berbagai media online; 2) membuat surat edaran kepada orangtua tentang pelaksanaan pembelajaran di rumah atau home learning ( BDR) dalam rangka meningkatkan kewaspadaan dan pencegahan penularan virus corona di sekolah; 3) melakukan sosialisasi kepada siswa mengenai media pembelajaran secara daring dan tata cara penggunaan media tersebut; 4) melakukan pengendalian dan pengawasan atas pelaksanaan pembelajaran di rumah yang telah ditugaskan kepada guru; 5) melaporkan hasil kegiatan belajar di rumah kepada dinas pendidikan (kompas.com, 2020).

Tugas guru antara lain 1) menyiapkan bahan ajar yang akan diunggah atau disebarkan kepada siswa melalui media atau aplikasi pembelajaran yang dipilih;2) guru menentukan media belajar yang sesuai dengan kondisi siswa agar belajar di rumah dapat berjalan secara efektif. Beberapa media yang dapat dipilih antara lain; grup Whatsapp, email, Google Clasroom, atau aplikasi media belajar lain rekomendasi Kemendikbud; 3) guru mengunggah media pembelajaran berupa modul, tutorial, video, latihan soal, lembar kerja siswa ke media yang telah ditetapkan atau disepakati bersama; 4) guru wajib memberikan penjelasan atas pertanyaan yang disampaikan siswa; dan 5) guru memeriksa dan melakukan evaluasi atas proses pembelajaran daring atau belajar di rumah ini untuk mendapatkan umpan balik hasil pembelajaran.

Tugas siswa yaitu mempelajari bahan atau materi mata pelajaran diunggah guru melalui media yang telah disepakati. Siswa dapat melakukan diskusi dengan guru melalui media online jika masih ada hal yang kurang jelas dari materi yang diberikan.

Tugas orangtua 1) memastikan siswa melaksanakan kegiatan belajar di rumah masingmasing dan membatasi izin kegiatan di luar rumah; 2) melakukan koordinasi dengan wali kelas, guru atau sekolah; dan 3) membantu siswa menerapka pola hidup bersih sehat (PHBS) di rumah. 
Sedangkan langkah-langkah yang harus disiapkan pembelajaran luring yaitu Pra pembelajaran 1) menyiapkan RPP mengacu pada kurikulum darurat; 2) menyiapkan bahan ajar, jadwal dan penugasan kemudian mengirimkannya ke peserta didik/orang tua/wali melalui WA grup mata pelajaran/ paguyuban otangtua; 3) memastikan semua siswa telah mendapatkan lembar jadwal dan penugasan; 4) guru dan orang tua/wali siswa bertemu untuk menyerahkan jadwal dan penugasan diwajibkan melakukan prosedur keselamatan pencegahan Covid-19; 5) jadwal pembelajaran dan penugasan belajar diambil oleh orang tua/wali siswa sekali seminggu di akhir minggu dan atau disebarkan melalui media komunikasi yang tersedia.

Saat pembelajaran, 1) pembelajaran luring dibantu orang tua/wali siswa sesuai dengan jadwal dan penugasan yang telah diberikan; 2) guru dapat melakukan kunjungan ke rumah siswa untuk melakukan pengecekan dan pendampingan belajar. Jika ini dilaksanakan, wajib melakukan prosedur pencegahan penyebaran Covid-19; dan 3) berdoa bersama sebelum dan sesudah belajar.

Usai pembelajaran 1) setiap siswa mengisi lembar aktivitas sebagai bahan pemantauan belajar harian; 2) orang tua/wali siswa memberikan tandatangan pada tiap sesi belajar yang telah tuntas di lembar pemantauan harian; 3) penugasan diberikan sesuai dengan jadwal; 4) hasil penugasan berikut lembar pemantauan aktivitas harian dikumpulkan setiap minggu sekaligus mengambil jadwal dan penugasan untuk minggu berikutnya. Ini dapat juga dikirim melalui alat komunikasi; dan 4) muatan penugasan adalah pendidikan kecakapan hidup, antara lain mengenai pandemi Covid-19. Selain itu perlu dipastikan adanya konten rekreasional dan ajakan melakukan olahraga/kegiatan fisik dalam upaya menjaga kesehatan mental dan fisik siswa.

Sistem pembelajaran daring dan luring mau tidak mau harus dilakukan di tengah wabah covid-19. Sebab, tidak mungkin peserta didik dibiarkan saja libur panjang hingga menunggu covid 19 akan hilang. Dalam pembelajaran daring dan luring di sekolah ini pada masa pandemi covid-19 terdapat beberapa kendala seperti terbatasnya waktu pembelajaran karena waktu pembelajaran di kurangi sehingga materi yang di sampaikan tidak tuntas. Untuk pembelajaran luring kelemahannya yaitu terkendala internet yang lemot dan kuota internet yang terbatas (Risdianto dkk, 2020).

Hasil wawancara dengan guru guru sejawat dan juga pendapat penulis bahwa guru lebih senang mengajar dengan tatap muka, tapi dalam kenyataan bahwa masih mewabahnya Covid19 srta kebijakan secara nasional untuk tidak gegabah membuka sekolah tatap muka terbatas maka dalam pembelajaran di masa pandemi Covid 19 ini di sekolah ini menggunakan berbagai cara supaya pembelajaran tetap berjalan seperti menggunakan pembelajaran daring dengan menggunakan media social seperti aplikasi WhatsApp, Google Classrom, Google Meet, Edmodo dan Zoom. Supaya dalam peroses pembelajaran bisa berjalan lancar guru harus memandu pembelajaran terlebih dahulu, dalam pembelajaran daring sebenarnya siswa lebih menyukai karena pembelajaran lebih menarik, membuat siswa menjadi penasaran dalam prosesnya membuat siswa menjadi aktif. Akan tetapi terkadang menemukan kendala seperti terdapatnya siswa yang tidak mengerjakan tugas dengan alasan tidak memiliki fasilitas teknologi yang mendukung seperti smartphone di karenakan orang tua dari siswa tersebut tidak mampu membelikan atau di rumahnya hanya ada satu saja sehingga bergantian dengan keluarganya yang lain, tidak adanya sinyal di tempat mereka tinggal, dan tidak adanya pulsa yang memadai. Di karenakan kendala tersebut maka sekolah ini mencoba menggunakan pembelajaran luring dengan tatap muka akan tetapi siswa dibatasi untuk hadir yaitu hanya yang betul betul tidak memiliki fasilitas pembelajaran baik gawai, laptop, wifi atau kehabisan paket data. Yang mengalami kendala seperti itu ternyata jumlahnya tidak banyak sekitar 1 s.d 3 orang dalam sehari. Dalam proses pembelajaran, waktu pembelajaran juga dibatasi satu jam pelajaran hanya 60 menit dalam satu hari dua mata pelajaran, akan tetapi sekolah juga tidak memaksakan siswanya untuk memilih pembelajaran luring karena hampir sebagian besar siswa masih melakukan pembelajaran daring, jadi presentasi dari yang melakukan pembelajaran daring 
kurang lebih sejumlah 99\%. Meskipun hasil survei hampir 100\% menghendaki sekolah tatap muka jika pandemic Covid-19 berlalu.

Jadi dilihat berdasarkan proses pembelajaran daring atau luring yang dilaksanakan di sekolah ini peran guru tidak bisa digantikan dengan apapun. Untuk itu semoga tidak ada lagi guru yang di kriminalisasikan lagi dalam upaya mendisiplinkan siswa, karena berkat gurulah bangsa kita ini mendapatkan generasi yang sesuai diamanatkan UU Sisdiknas. Semoga nantinya pandemi Covid-19 ini segera berakhir agar pembelajaran bisa di laksanakan seperti biasanya.

\section{KESIMPULAN}

Sejak kasus Covid-19 mulai meningkat, sekolah atau universitas tidak lagi melakukan aktivitas seperti biasa, karena pemerintah memberlakukan sistem pembelajaran di rumah saja, salah satu langkah yang tepat untuk mengatasi masalah ini adalah menggunakan teknologi jaringan dan informasi bagi sistem pembelajaran terutama di sekolah, dalam perosesnya banyak sekali kendala-kendala yang di hadapi oleh guru yang di mana pembelajaran daring ini baru pertama kali dilakukan seperti terkendala dengan sinyal dan lain-lain, akan tetapi kendala tersebut bukan menjadi penghalang untuk mendidik dan mencerdaskan peserta didik, seiring berjalannya waktu pemerintah mengizinkan pihak sekolah untuk membuka secara bertahap pembelajaran di sekolah maka terciptalah pembelajaran luring melalui tahapan sosialisasi dan simulasi pembelajaran tatap muka (PTM) dengan mematuhi stadar prokes yang ketat. Setiap pembelajaran terkadang adanya kelebihan dan kekurangan termasuk pembelajaran daring dan luring di masa pandemi Covid-19 ini, akan tetapi dari sistem pembelajaran daring dan luring diharapkan guru untuk kreatif dalam mendidik peserta didik., sehingga keberhasilan pembelajaran bisa tercapai dengan baik atau efektif.

\section{DAFTAR PUSTAKA}

Abdullah, A. (2020). Relationship the Work Culture and Training Programs Within Performance. International Journal of Progressive Sciences and Technologies (IJPSAT), 20(1).

Amalia, D. (2019). Promoting Just Culture For Enhancing Safety Culture In Aerodrome Airside Operation. International Journal of Scientific \& Technology Research 8 (10)

Apriani, N., Fatonah, F., \& Oka, I. A. M. (2020). Rancangan Sistem Pengolahan Sertifikat Berbasis Website Sebagai Upaya Untuk Peningkatan Evaluasi Kompetensi Safety Personil Di Lingkungan PT Angkasa Pura II (Persero). Langit Biru: Jurnal Ilmiah Aviasi, 17-28.

Fitria, H., \& Suminah, S. (2020). Role of Teachers in Digital Instructional Era. Journal of Social Work and Science Education, 1(1), 70-77.

Hamzah, S., Yussof, M. H. B., \& Enriquez, A. A. (2020). Togetherness in the Diversity of the Pancasila Ideology Frame. Journal of Social Work and Science Education, 1(1), 8-12.

https://www.kemdikbud.go.id/main/blog/2020/05/kemendikbud-terbitkan-pedomanpenyelenggaraan-belajar-dari-rumah.

Ivanova, T., Gubanova, N., Shakirova, I., \& Masitoh, F. (2020). Educational technology as one of the terms for enhancing public speaking skills. Universidad y Sociedad, 12(2), 154159.

Komalasari, K., Arafat, Y., \& Mulyadi, M. (2020). Principal's Management Competencies in Improving the Quality of Education. Journal of Social Work and Science Education, $1(2), 181-193$

Kristiawan, M. (2014). A Model for Upgrading Teachers Competence on Operating Computer as Assistant of Instruction. Global Journal of Human-Social Science Research.

Kristiawan, M., \& Muhaimin, M. (2019). Teachers' Obstacles In Utilizing Information and Communication Technology. International Journal of Educational Review, 1(2), 5661. 
Listiningrum, H. D., Wisetsri, W., \& Boussanlegue, T. C. H. A. B. L. E. (2020). Principal's Entrepreneurship Competence in Improving Teacher's Entrepreneurial Skill in High Schools. Journal of Social Work and Science Education, 1(1), 87-95.

Murkatik, K., Harapan, E., \& Wardiah, D. (2020). The Influence of Professional and Pedagogic Competence on Teacher's Performance. Journal of Social Work and Science Education, $1(1), 58-69$

Nugraha, W. (2019) Safety Documentation: A Communication Approach For Safety Management System In Aerodrome Operator. International Journal of Scientific \& Technology Research 8 (11), 1705-1711

Republik Indonesia. (2003). Undang-Undang Sistem Pendidikan Nasional No 20 tahun 2003. Sekretariat Negara. Jakarta

Risdianto, E., Fitria, J., Johan, H., \& Macariola, J. S. (2020). Teacher's Perception of Thermodynamic Law Module Developed in Training through Student's Critical Thinking Skills. Journal of Social Work and Science Education, 1(1), 78-86.

Rohma, S., Harapan, E., \& Wardiah, D. (2020). The Influence of School-Based Management and Teacher's Professionalism toward Teacher's Performance. Journal of Social Work and Science Education, 1(1), 13-23.

Septiani, V., \& Cahyono, D. (2019). Education and Training Strategy in Palembang Aviation College. International Journal of Recent Technology and Engineering, 8 (3)

Soleh, A. M., Tobari., Kesumawati, N. (2019). Development of The Practical Manual As A Learning Media For Simulator Aircraft Rescue And Fire Fighting. International Journal of Scientific \& Technology Research 8(10).

Sugiyono. (2017). Metode Penelitian Kuantitatif, Kualitatif, dan R\&D. Bandung: Alfabeta.

Zulaiha, D., Lian, B., \& Mulyadi, M. (2020). The Effect of Principal's Competence and Community Participation on the Quality of Educational Services. Journal of Social Work and Science Education, 1(1), 45-57.

https://www.kompas.com/edu/read/2020/06/16/200131471/pembelajaran-jarak-jauh-bukanpembelajaran-daring-ini-penjelasannya. 